\title{
Introduction: markets, planning and democracy in the age of post-communism
}

Contemporary society cannot flourish without markets, and therefore private or separate property rights in the means of production.

When Ludwig von Mises and F.A. Hayek advanced this argument in the 1920 s and 1930s, they faced waves of criticism from defenders of market socialism, most notably Oskar Lange and Abba Lerner, but also from their Austrian colleague Joseph Schumpeter, in his magnificent but flawed book, Capitalism, Socialism, and Democracy (1950).

For the most part Mises and Hayek had geared their critique of socialism to central economic planning. In response, market socialists generally agreed that truly centralized economic planning had little basis in economic theory; instead they promoted a form of socialism that apparently allowed for markets and prices in consumer goods, and the imputation of consumer goods prices through the state-owned capital structure. Their theoretical solution earned the respect of the economics profession for years to come. Market socialism was considered at least consistent with neoclassical economic theory, and the Austrians were viewed as losers in the great socialist calculation debate, as it came to be called.

A renewed appreciation for the Austrian position would appear only by the late 1980s, as the problems of 'really existing socialism' came to a head. The collapse of the former Soviet Union and other socialist countries throughout Eastern Europe from the Fall of 1989 onward seemed finally to validate the Mises-Hayek case against central planning, and also cast serious doubt on the market-socialist hybrid.

It was during this time, a couple years before the Fall, that I began working in comparative political economy, using the Austrian theory of the market process. My first book, Marxism and Workers' Self-Management: The Essential Tension (1991), grew out of my George Mason University dissertation. There, I attempted to apply the Austrian argument to the theory of decentralized socialism, a theory championed especially by a group of Marxist academics in the former Yugoslavia, who disdained Soviet-style central planning and showed little appreciation for the neoclassical models 
of market socialism. I felt that the Austrians tended to focus almost exclusively on central economic planning - indeed, they seemed to equate socialism with central planning - and I hoped to extend the argument to self-managed socialism, represented in part by the efforts of Michael Albert and Robin Hahnel, but especially by the work of Branko Horvat (Yugoslavia's leading economist) and the Praxis Group (a group of Croatian and Serbian philosophers who attempted to resurrect the humanistic Marxian vision of radically democratic, decentralized planning).

I continued the common Austrian theme that contemporary society can flourish only with markets, and therefore private or separate property rights in the means of production. I argued that decentralized or self-managed socialism must fail because it, too, seeks to destroy the market process in capital goods. I also argued that central planning is one form of comprehensive economic planning; decentralized planning is the other. And so the problem should not be equated with central planning per se; the same epistemological difficulties appear with decentralized planning. Comprehensive economic planning - whether of the idealized Soviet-style, top-down variety or the idealized Yugoslav-style, bottom-up variety - cannot withstand the Austrian School test. Either approach to comprehensive planning, whether by command from above or radically democratic initiative from below, cannot demonstrate how dispersed and incomplete knowledge would be garnered to coordinate the capital structure.

\section{THE FAILURE OF SELF-MANAGED SOCIALISM}

I attempt to clarify further and extend my argument in this present book, particularly in Part One. Chapter 1 offers a general discussion of the Austrian theory of comparative economic systems, juxtaposed against Marxism. In Chapter 2 I examine the Albert-Hahnel model of decentralized socialism (among others), and in Chapter 3 I specifically address Horvat's alleged 'answers' to Hayek. I find that both models assume away what must be addressed by anyone seriously working in comparative political economy today: how, under a system of social ownership and nonmarket prices, would workers' councils and their elected representatives in the planning process tap the kinds of knowledge and information that are required for plan coordination?

A system of self-managed workers' councils, without the guidance of spontaneously-formed prices of consumer and especially capital goods, will fail to find an effective way to calculate the relative scarcities of those goods. They would face, as Mises argued back in 1920, a 'bewildering throng of possibilities'. It's not a matter of improving the vote, the talk, or the tech- 
nology. Neither radical democracy, nor a more radically vocal Mihailo Marković, nor Cisco Systems can save socialism. Socialism as a system of comprehensive planning cannot be saved. Millions of often conflicting plans can only be coordinated through the institutions of a market process.

\section{THE ESSENTIAL TENSION BETWEEN DECENTRALIZATION AND CENTRALIZATION, DEMOCRACY AND COMMAND}

Even the purely theoretical vision of self-managed socialism betrays its own radically decentralized ideal by promoting centralized coordinating mechanisms. Although self-managed socialism holds radical democracy as the political ideal, the economic logic of comprehensive economic planning tends toward hierarchy and centralization, pulling away from the ideal of decentralized control over socially owned means of production. We witnessed this tension in Yugoslav practice (the subject of Chapter 3, and discussed in more historical detail in Chapter 4), but its roots are exposed even in the pure theory of self-managed socialism.

The roots of the tension between decentralization and centralization go back to Marx himself. Many readers see in Marx a case for the abolition of capitalism in favor of centralized economic planning. This was the typical Austrian view, too - Marx as command planner. The Yugoslav Praxis Group, however, offered an alternative reading of Marx, one that emphasized his praxis theory, his theory of alienation and exploitation, and the implied vision of socialism that is supposed to put an end to alienation and allow man 'to return to himself'.

In a review of my book, Steve Pejovich maintained that I gave 'too much credit to the so-called praxists and their interpretation of Marx' (1991). He views their interpretation of Marx as a ploy reflecting their self-interested attempt to market themselves to left-wing radicals in the West. While that may be partly true (indeed, it had taken a $180^{\circ}$ turn for the worse: Mihailo Marković threw out all his earlier arguments and became the chief intellectual ideologist within Slobodan Milosević's Serb nationalist campaign in the 1990s!), the praxis-philosophy interpretation of Marx can be examined outside any peculiar motivations that might have been harbored by members of the Praxis Group. If we take their interpretation of Marx seriously, as I do, then surely the Stalin-style central planning board, even in theory, does not attempt to totally eliminate the kind of alienation that terrified Marx. Rather, the central planning board becomes, de facto, a universal capitalist controlling all the means of production.

But Marx himself struggled with the ideal of decentralization and 
workers' self-management on the one side, and the implicit logic of centralization and coordination to make comprehensive economic planning effective. This is the subject of Chapters 5 and 6 . Of course, markets for the means of production cannot be reconciled with Marxian socialism. But central economic planning procedures, too, cannot be reconciled with a self-managed socialism worthy of the name. Marx struggled - and in my opinion, failed - to eliminate this tension. So, too, did the Praxis Group as a whole.

\section{A HAYEKIAN SOCIALIST STANDING AMIDST PREOBRAZHENSKY AND STALIN?}

We all know actions have unintended consequences. And I've learned the hard but humorous way that also includes scholarly debate.

My interest in the 'humanistic' interpretation of Marx, as critical as it is, spurred some rather incredible interpretations of my own work. Peter Abell, for example, has interpreted my efforts as trying to build a 'postmodern' case for self-managed socialism. Abell has gone so far as to say that I try to salvage a case for workers' self-management by focusing on Marx's praxis philosophy. (I rebut him in Chapter 6.) John Bellamy Foster interprets me as some kind of 'Hayekian Socialist' (mentioned in Chapter 8). And most glaring of all, I'm listed on some crazy website as one of the more important twentieth century Marxists, standing alphabetically (though not ideologically, to be sure) between Preobrazhensky and Stalin! (I'll let you track that one down yourself.) I plead not guilty to all of these ridiculous charges, and unlike Bukharin, who was purported to use Aesopian language at his tribunal, I have written as clearly and straightforwardly as I can in the essays in this book.

\section{SELF-MANAGED FIRMS IN A MARKET PROCESS}

Perhaps some of the confusion stems from my Austrian defense of selfmanaged firms. Both the attempts at central planning and self-managed socialism are failures. But, as I argue in Chapters 6, 7, and 8, (and later in Chapter 10), a case can be made for self-managed firms within the institutions of an open market process.

This is certainly not socialism. Nor, however, is it capitalism in the conventional sense of the term. I argue that a market economy comprised of self-managed enterprises is consistent with Austrian School theory. It retains private or separate property rights in the means of production, and 
the competitive bidding process and spontaneously-formed prices that reflect relative scarcities. It is fundamentally a market system (rather than 'socialist' or 'third way') that doesn't seem to face the epistemological hurdles (expressed by Mises and Hayek, or my contemporary colleagues Lavoie and Boettke) that prohibit rational economic calculation. Democracy appears at the level of individual enterprises, which is the essence of a self-managed firm. Democracy does not appear within some hypothetical comprehensive planning apparatus, for market processes are incompatible with a set of comprehensive plans.

Yes, planning does occur - and it occurs in any economic system, as Hayek found necessary to remind us. This issue is not 'planning versus no planning'. Instead, the issue is over who will be engaged in planning. It's a matter of appropriate institutions. A market system is a set of institutions that allows individuals, on their own or collaborating in organizations, to coordinate their plans. They are economically guided by relative prices and profit-loss accounting, and engage in the free exchange of property rights. The standard literature on workers' self-management has for too long remained content modeling self-management by reference to the firm's objective function, largely independent of its institutional context, whether those institutions are genuinely market-based, market-socialist, or socialist. I argue that, at least as a theoretical exercise in comparative political economy, a market system composed of self-managed firms can be shown to work. And, depending upon one's normative positions, it might be preferred to state or corporate capitalism.

In a way, I hope that my work begins to bridge the gap between Jaroslav Vanek, the leading defender of the principle of workers' self-management, and Steve Pejovich, the leading critic of its implementation in the former Yugoslavia. I am very pleased that Vanek (1996) has come to agree with my Austrian call for the necessity of market processes to coordinate the plans of self-managed firms, and that Steve Pejovich (in friendly conversation) has also come to agree (or at least disagree much less!) that my vision of self-managed firms operating within an open market process - without state intervention - is coherent in principle.

\section{AUSTRIANS ON ANARCHO-CAPITALISM}

My defense of self-managed firms represents a departure from the traditional Austrian defense of the market system. In Part Two I take the opportunity to challenge further some Austrian views of the market process, particularly the more utopian variants dressed up in the rhetoric of scientific certainty. 
I have no doubt about the necessity of the market process. I must admit, however, that I have not been satisfied with the scientific assuredness of market outcomes in the Austrian theory of welfare economics, particularly with Murray Rothbard's praxeological approach. Rothbard claimed to offer a purely deductive, and apodictically true, case for total non-intervention in the market process. Although Rothbard also claimed to be engaging in a 'radically empirical' approach to studying economic systems, he failed to view market processes institutionally. I argue that his purely praxeological exercises are misleading and flawed, and his own case for the welfaremaximizing properties of free markets is theoretically and empirically unfounded. I examine Rothbard's approach, and Roy Cordato's more recent updating, in Chapter 9. Following Rothbard, Cordato implicitly argues for anarcho-capitalism, maintaining that the free market is the 'ideal institutional setting' for maximizing efficiency and social welfare. Both argue that any degree of state intervention cannot possibly improve efficiency and/or social welfare. This might be true. But neither Rothbard nor Cordato have demonstrated its validity.

My sentiments regarding the robust properties of the market process lie, of course, with Rothbard and Cordato. I even retain sentimental feelings for market-based anarchism. But sentiments aren't enough to make a clear scientific case - let alone some alleged praxeological proof - of the maximizing properties of market systems. I argue that both Rothbard and Cordato fail to meet their own scientific standards, and thereby fail to live up to their unqualified defense of the anarcho-capitalist ideal.

Rothbard, of course, was the twentieth century's leading defender of anarcho-capitalism. I further challenge Rothbard, and juxtapose his case for anarchism against Murray Bookchin's anarcho-communist variant, in Chapter 10 (Bookchin being the leading defender of anarcho-communism). I critically examine Rothbard's scientific case against self-managed firms, as well as Bookchin's moral case against markets and private or separate property rights. Bookchin's left-wing anarchist theory is flawed because it fails to recognize the insurmountable knowledge problems that arise when markets for the means of production are abolished. He demonstrates no understanding of economics. But Rothbard's corresponding call for the necessity of anarcho-capitalism does not persuade. Rothbard has shown us that anarchism - if it is to work conceptually at all - must be market-based, but his case against self-managed enterprise is weak. (Apparently, for Rothbard and many Austrians, self-managed firms have no part in a truly 'capitalist' economy, not even in principle.) In Chapter 10 I sketch the possibility of conceiving a market-based anarchist system with an expanded range of firms, from the traditional capitalist enterprises championed by the Right to the self-managed and cooperative enterprises championed by the Left. 


\section{DOES THE MARKET WIN BY DEFAULT?}

The Fall of 1989 opened up new vistas for theorists in comparative political economy, and created quite a bit of excitement among classical liberals in general, including myself. But it is now over a dozen years later, and it still remains unclear just how much a genuine market process, and its potential for personal and political freedom, will emerge in its aftermath.

The remaining chapters in Part Two focus, therefore, on a variety of issues wedded to post-communism. In Chapter 11 I discuss the allure of the welfare state as the Left's next-best alternative to really existing socialism, with a focus on Claus Offe's argument about the irreversibility of the welfare state, and Schumpeter's theory of the potential collapse of the tax state. In Chapter 12 (a paper written specifically for this volume) I turn to Joseph Stiglitz's call for a 'new' model of market-based socialism, which doesn't appear to be much different from Schumpeter's old market socialism. I address the role of conservatism and radicalism in Hayekian social theory in Chapter 13, and in particular I defend his remarks on the role of tradition (tradition without a capital T). In Chapter 14 (a previously unpublished address of mine) I offer some reflections on the rise of nationalism and other transition problems in post-communism. I conclude the book in Chapter 15 with a brief essay that addresses my normative vision, and the motivation behind my criticisms of Austrian economic theory. Some readers might wish to read this chapter first.

Although it is mighty tempting to rewrite and improve upon some of my previously published articles, I have left them largely untouched, except for non-substantive changes that improve their stylistic consistency. 
David L. Prychitko - 9781843767381 Downloaded from PubFactory at 04/26/2023 12:38:12PM via free access 